<原 著 $>$

各種肝疾患における血清中 Thrombomodulin の臨床的意義

一急性肝不全を中心として一

\begin{tabular}{|c|c|c|c|c|c|c|c|}
\hline 森 & 健治* & 白沢 & 宏幸* & 奥田 & 道有* & 萱野 & 幸三* \\
\hline 山下 & 仰* & 久保田 & 政文* & 竹中 & 一行* & 山下 & 智省* \\
\hline 中田 & 功* & 佐貫 & 和俊** & 安永 & 満* & 福本 & 陽平* \\
\hline 喵 & 極 ${ }^{*}$ & & & & & & \\
\hline
\end{tabular}

要 旨：急性肝不全(ALF)を中心として各種肝疾患に扎いて，血管内皮細胞の障害のマーカー である Thrombomodulin（TM）を測定し，臨床的意義を検討した．急性肝不全では，血清中 TM 濃度は急性肝桨に比し有意に上昇していた。 また血清中 TM 濃度は血清クレフチニン濃度 と有意の相関を示していた。そこで腎不全のない時点での急性肝矣患の血清中 TM 浱度を比較 すると，やはり急性肝不全では，急性肝炎に比し有意に上昇していた。しかし播種性血管内凝 固症候群 (DIC) のマーカーであるトロンビン・アンチトロンビンIII複合体（Thrombin・ Antithrombin III complex, TAT)とは相関はみられなかった。このことから，血清中 TM 濃 度は急性肝不全の進展を把握するマーカーになりらると推定された。さらに今後，肝静脈血中 の TM を測定し TAT との関連を検討することで, 障害発現のメカニズムを解明していく必要 があると考えられた。

事引用語：Thrombomodulin 血管内皮細胞 急性肝不全 DIC 腎不全

\section{緒 言}

急性肝不全 (ALF) は，全身諸窚器の障害を引き起 こし多臓器不全に至ることから，予後不良の疾患とさ れている.現在多くの肝機能のマーカーについて検討 されているが，いずれる肝細胞自体の機能を反映する るのがほとんどであり，肝不全の発症機序に深く関 わっていると推定されている肝非実質細胞に関する臨 休的な検討はほとんどなされていない。

そこで著者らは，重篤な肝不全状態においては肝細 胞壊死とともに肝血管内皮細胞の破壊も惹起されてい ると考えられることから，その障害を反映すると報告 されているトロンボモジニリン (Thrombomodulin, TM）を血清中で測定し，その臨床的意義を検討した。 また慢性肝疾患例においても同様に娭討を加えた。

\section{対象と方法}

対象は，健常人12例，急性肝疾患17例抒上び慢性肝 疾患45例であり，測定にあたっては血清を用いた。急

- 山口大学医学部第 1 内科

**同総合診療部

〈受付日1991年 7 月31日 $>$
性肝疾患例の内訳恃急性肝炎 8例（そのうちプロト口 ンビン時間 $40 \%$ 以下の重症型 4 例)，劇症肝炎 6 例(急 性型 2 例, 亜急性型 4 例), Late onset hepatic failure 1 例, 自己免疫性肝炎劇症化 1 例, Acute on chronic 1 例, 慢性肝薙患例の内訳は, 慢性肝炎18例, 肝硬変 16例(代供期 3 例，非代供期13例)，肝細胞癌11例であ る.なお，急性肝障害群では経日的に血清中 TM を测 定した.

測定方法は石井ら"の方法に準じて抗ヒト TMモ， クローナル抗体 (TMmAb)を用いた ELISA kit (MGC-01-001，三菱瓦斯化学社製）で測定した。

まず96穴マルチウェル・プレートに200 $\mu l の 1$ 次抗 体 (TMmAb-20) を $4{ }^{\circ} \mathrm{C}$, “over night”で固相化し, $100 \mu l$ の 2 次抗体 (TMmAb-2，11)を加之，直ちに標 集 TM（Salem らの方法でヒト胎盤から精製したも の), または測定試料 $100 \mu l$ を加え 2 時間室温で静置し た後，0.05\%Tween を含をPBS 緩衝液で洗浄を繰り 返し, HRP 基質液 $200 \mu l$ を加方室温で 15 分間反応させ た。 その後 $4 \mathrm{~N}$ 硫酸で反応を止め, $490 \mathrm{~nm}$ の波長で吸光 度を測定した。なお統計学的処理はStudent's pair 
test および回㷌分析法を用いて行った。

\section{成 績}

各種肝疾患における血清中 TM 濃度の平均值は Fig. 1 の如くであった. な扰急性肝不全症例では経過 中の最高值を示す．急性肝不全は85.6 $30.3 \mathrm{ng} / \mathrm{m} l$ で, 急性肝炎 $24.6 \pm 9.00 \mathrm{ng} / \mathrm{m} l$, 急性肝炎重症型 $31.3 \pm$ $6.59 \mathrm{ng} / \mathrm{m} l$ に比し, 危険率 $1 \%$ 以下で有意に高值を示

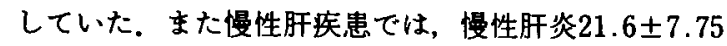

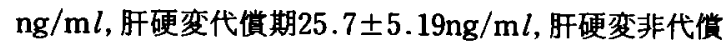
期 $33.8 \pm 9.35 \mathrm{ng} / \mathrm{m} l$, 肝細胞癌 $30.5 \pm 12.1 \mathrm{ng} / \mathrm{m} l$ と, 健常人 $13.6 \pm 2.62 \mathrm{ng} / \mathrm{m} l$ に比し，危険率 $1 \%$ 以下で有 意に高値を示していた。

次に，急性肝不全症例ではしばしば腎不全を合併し ているため，急性肝不全应例において血清クレアチニ ン涱度と TM 莀度の相関を険討した(Fig. 2). 血清ク レフチニン濃度と TM 濃度は危険率 $1 \%$ 以下で有意 に正の相関を示していた，血清中 TM 濃度は，腎不全 の合併により上昇することが判明した，そこで，急性 肝疾患症例で血清クレフチニン濃度 $1.5 \mathrm{mg} / \mathrm{d} l$ 以下の 時点におりるすべての血清中 TM 濃度について検討 した．急性肝不全では $34.7 \pm 9.57 \mathrm{ng} / \mathrm{m} l$ で, 急性肝炎 $23.8 \pm 7.23 \mathrm{ng} / \mathrm{m} l$, 急性肝炎重㱏型 $23.4 \pm 5.00 \mathrm{ng} / \mathrm{m} l$ に比し，危険率 $0.1 \%$ 以下で有意に上昇していた（Fig.

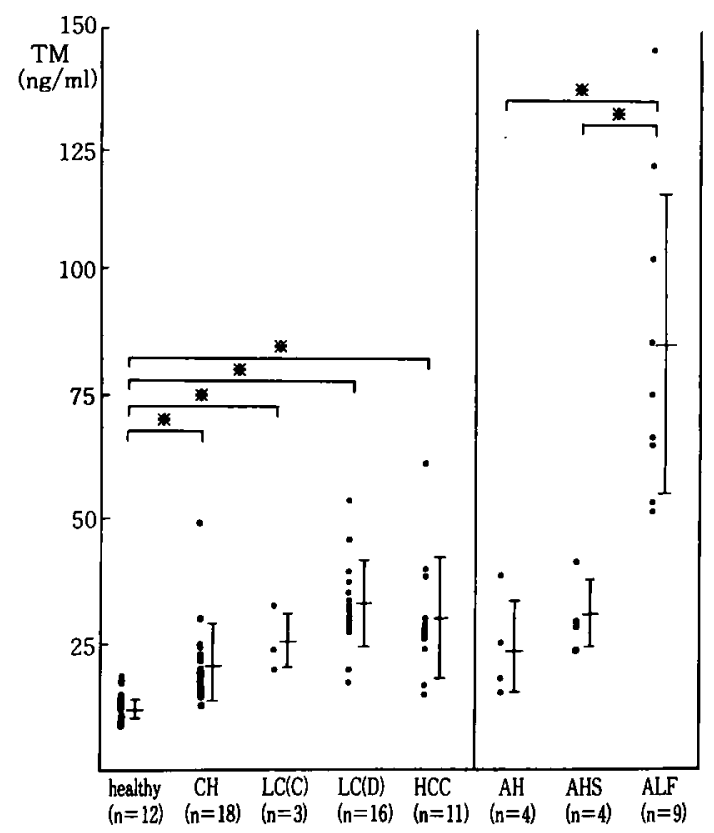

Fig. 1 Maximum serum TM conc. in the patients with various liver diseases. " $: p<0.01$

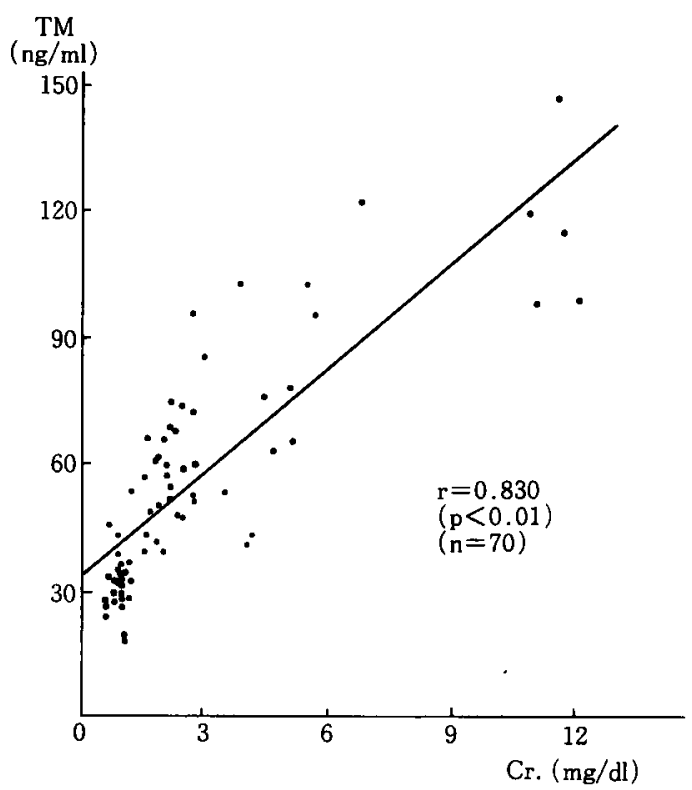

Fig. 2 Correlation between serum TM and creatinine conc. in the patients with acute liver failure.

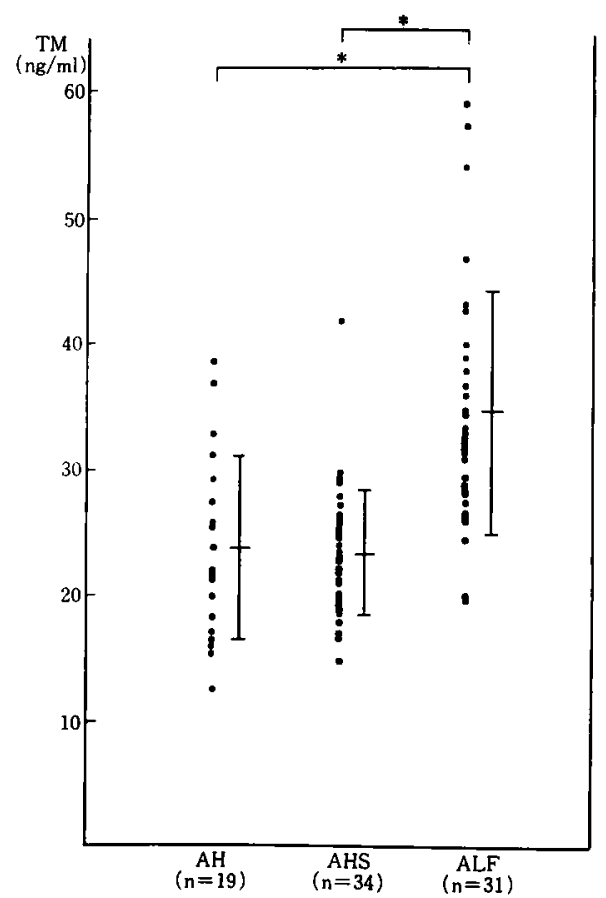

Fig. 3 Serum TM conc. in the patients with acute liver injury without renal failure. ${ }^{*}: \mathrm{p}<0.001$ 

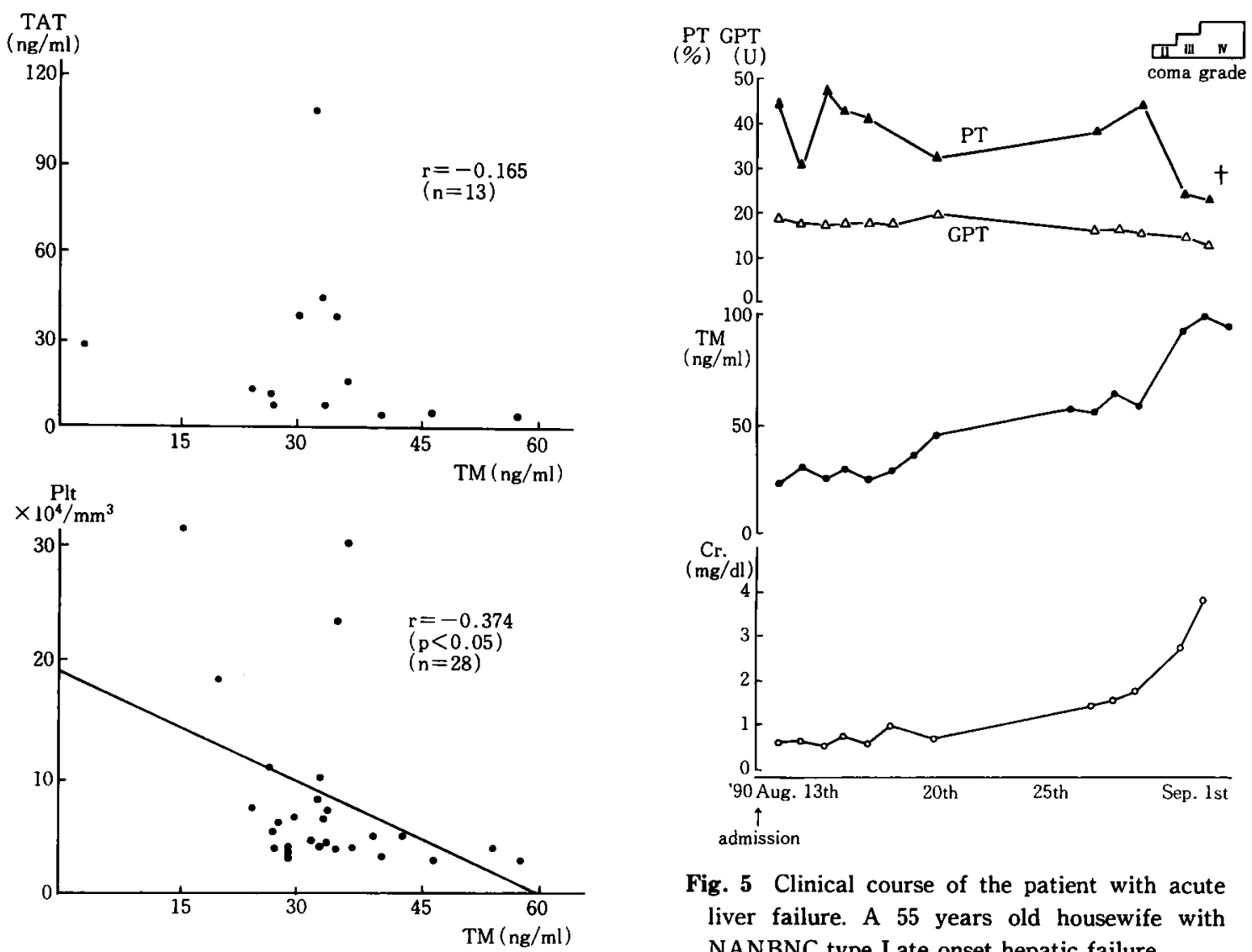

Fig. 5 Clinical course of the patient with acute liver failure. A 55 years old housewife with NANBNC type Late onset hepatic failure.

Fig. 4 Correlation between serum TM and TAT conc. in the patients with acute liver failure without renal failure.

3).

次に急性肝不全症例で血清クレフチニン濃度 1.5 $\mathrm{mg} / \mathrm{d} l$ 以下の時点における血清中 $\mathrm{TM}$ 濃度と DIC の 指標となるトロンビン・フンチトロンビンIII複合体 (Thrombin-Antithrombin III complex, TAT) と血 小板数の相関について検討した (Fig. 4). 血小板数と は危険率 $5 \%$ 以下で負の相関関係が認められたもの の, TAT 浱度とは全く相関関係は認められなかった。 代表的症例呈示する (Fig. 5).

症例：55歳, 女性, Late onset hepatic failure (HAV，HBV ならびに HCV の感染マーカーはいず 九陰性)

平成 2 年 6 月 10 日, 全身倦怠感, 食思不振を自覚し たが放置．症状が徐々に増強したため，7月 3 日近医 を受㡎し, GOT 1,239IU, GPT 1.556IU, T. bilirubin $4.23 \mathrm{mg} / \mathrm{d} l$ ， ヘパブスチンテスト $47 \%$ と著明な肝機

能障害を認め同院に入院. 入院後黄㡺は増強し,プロ トロンビン時間は20 30\%を推移し，劇症肝炎への移 行が疑われたため，8月 9 日当科紹介入院となった。 当科入院後, タルカゴン・インシュリン療法, 血装交 換療法，プロスタグランジン $\mathrm{E}_{1}\left(\mathrm{PGE}_{1}\right)$ ならびに epidermal growth factor (EGF) の投与を行ったが, 第82病日に肝性昏睡II度となり，第86病日に死亡した。 本症例では，艮機能障害を認めず，また意識障害が発 現する前の時期にすでに血清中 TM 瀑度は上昇し，堅 機能障害の増悪とともに血清中 TM 嶩度も更に上㫒 していた。

次に慢性肝疾患における血清中 TM 濃度の意義に ついて検討した。血清中 TM濃度は血清フルブミン 値, コリンエステラーゼ値と危険率 $1 \%$ 以下，プロ卜 ロンビン時間と危険率 $5 \%$ 以下で有意に負の相関を認 めならびに ICGR 15 值と危険率 $1 \%$ 以下で有意に正 の相関を示していた（Fig. 6). 

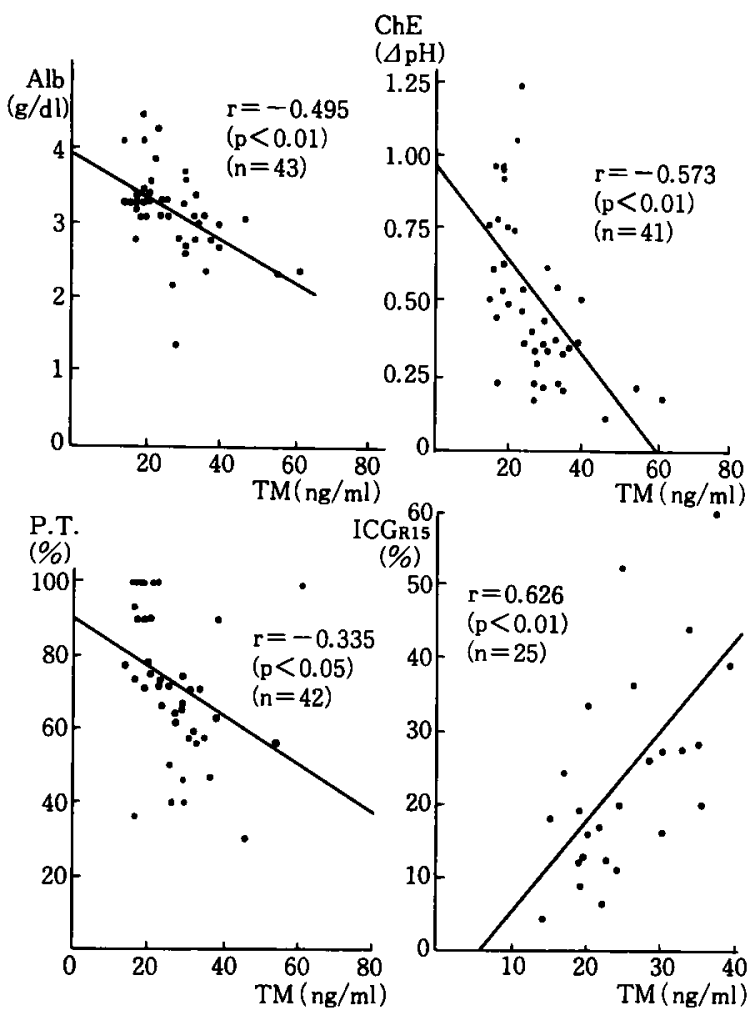

Fig. 6 Correlation between serum TM conc. and Albumin, Cholinesterase, Prothrombin time or ICGR $_{15}$ in the patients with chronic liver disease.

\section{考 察}

Thrombomodulin（TM）は, 1981年 Esmon $と$ Owen ${ }^{31}$ にっって発見された分子量が約105,000の血管 内皮細胞に特異的な煻蛋白で，脳微小血管以外の血管 内皮細胞の膜表面を貫通する形で存在している。 また トロンビンと強い親和性をもって結合して，その血液 凝固活性を阻害することが知られている。石井らはは TM が血管内皮細胞のみではなく，血中および尿中に も分布することを報告し，その由来は血管内皮細胞が 障害を受けて，細胞内プロテアーゼで低分子に分解さ れ，後に血中に逸脱したものと述べている.

血清中 TM 浱度が高值を示す代表的な疾患は，全身 エリテマトーデス，播種性血管内凝固症候群，堅不全， 糖尿病などが挙げられる。これらの疾患はいずれも全 身性の血管病変を合併しており，局所的な血管病変で ある閉塞性動脈硬化症, 急性心筋梗塞, 肺動脈塞栓症 なとでは血清中 TM 濃度は健常人のそれと差がな かったと報告されているいて6).
血清中 TMの代謝とその排泄については全く不明 である. 尿中 TM の由来は腎そのものから分泌されて いる7,8)ものだけであるのか，あるいは血清中で認めら れる TM る排泄されているのか明らかにされていな

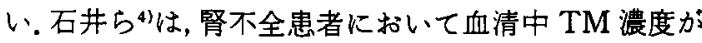
高値を示すことに関して，(1)尿中 TMにも血清中 TM と同様に分子量が約 105,000 といら高分子の TM が存 在すること，(2)ネフローゼ症候群で尿中に多量のタン パク質が漏出しても，TM は尿中へ健常值を越えて漏 出せず，血中でも異常が認められないこと，(3)動物実 験で家鬼の腎動・静脈を結紮しても血清中 TM 濃度は 上昇しないことなどから，祭不全時に血清中 TM 濃度 が高値を示すことが単に腎臓での滤過低下だけで説明 するのは困難であるとしている。したがってこの点を 明確にする意味で，堅不全を合併した肝不全症例に揖 いては，血清中，尿中 $\mathrm{TM}$ と血清中，尿中クレアチニ ン濃度を測定し，TMのクリフランスを求めることが 必要となってくるであろら。

肝疾患と血清中 TM 濃度の測定は, Iwabuchi $5^{9)}$ に よりすでに報告されているが，現在まで肝疾患におけ る血清中 TM 濃度の臨床的意義を詳細に検討した報 告は見あたらない，そこで今回著者らは急性肝疾患症 例を中心に血清中 TM 濃度の臨床的意義について検 討した。

急性肝不全症例の血清中 TM 濃度は急性肝炎（重症 型む含め）に比し，有意に上昇していた。しかし急性 肝不全症例では血清クレフチニン濃度と血清中 TM 濃度が危険率 $1 \%$ 以下で有意に正の相関関係を示して いたことから，血清中 TM 濃度は腎不全の増悪に伴い 上昇することが示唆された，そこで，腎不全のない血 清クレアチニン濃度が正常の時点での血清中 TM 濃 度について検討を加えた。この検討でるやはり急性肝 炎（重症型む含め）に比して，急性肝不全症例では血 清中 TM 濃度が有意に上异していた。このことは，急 性肝不全における血清中 TM 濃度の上昇が肝贜内の 血管内皮細胞障害に由来している可能性が示唆され る.したがって血清中 TM 濃度は急性肝不全の予後を 推定する指標になることが証明された，事実，著者ら は，腎機能障害を認めない時期にすでに血清中 TM 濃 度は上昇し，また腎機能障害の増悪とともに血清中 TM 濃度が更に上昇する症例を経験している。

急性肝不全で，堅不全の合併とともに重要なるのに 播種性血管内凝固症候群(DIC)がある。風間 ( $^{51}$ は DIC 極期で発症前より血清中 TM 湛度は高くなり，DICが 
回復すると低下したと述べている，急性肝不全におけ るDIC の診断は困難であるが，血清中 TM 濃度と TAT 濃度とは相関がなく，したがって血清中 TM 浱 度で全身性の DIC を診断することは困難であると思 われる。しかし局所的な肝内血管内皮細胞障害が肝不 全の発症あるいは進展に関与しているとする基礎的な 報告が多くみられ 関係をみることが重要である，それゆえ今後肝静脈血 中の TM の測定が必要であると考えられる.

次に慢性肝疾患においては血清中 TM 濃度は健常 人に比して上昇していたが，慢性肝炎，肝硬変の間に は，有意差は認められなかった。ささらに慢性肝疾患す べての症例に招ける血清中 TM 濃度は, アルブミン 值, コリンエステラーゼ値，プロトロンピン時間と負 の相関ならびに $\mathrm{ICGR}_{15}$ 值と正の相関を認めた，以上 より慢性肝疾患でも，血管内皮細胞の障害が存在して いると考えられるが，今後，肝線維化，血流量の変化 といった点からも検討する必要があろう.

\section{結 語}

急性肝不全を中心にして各種肝矮患における血清中 TM 濃度を測定し，以下の結論を得た。

1）急性肝不全では，血清中 TM 濃度は急性肝炎(重 症型を含め）に比し上昇していた。

2）血清中 TM 濃度は血清クレアチニン濃度と有意 の相関を示した。

3）堅不全を認めない時点での急性肝疾患の血清中 TM 濃度を比較すると，急性肝不全では急性肝炎扣よ び急性肝炎重症型に比し，有意の上昇を示した。

4）急性肝不全では，血清中 TM 濃度と血小板数と 負の相関がみられたが，TAT濃度とは相関はみられ なかった。

5）以上より，血清中 TM 濃度は急性肝不全におい て，障害発現のメカニズムおよび進展を把握する重要 なマーカーとなることが推定された。

6）慢性肝疾患では，血清中 TM 濃度は健常人に比 し上昇していたが，各疾患群の間には有意差は認めら れなかった。 さらにアルブミン値, コリンェステラー セ値，プロトロンビン時間と負の相関ならびに $\mathrm{ICGR}_{15}$ 値と正の相関を示していた。

本研究は厚生省(難治性の訮炎)調查研究費によって行わ れたことを付記し，感謝いたします。

\section{文献}

1) 石井秀美, 田中 明: Thrombomodulin の測定. Diabetes J 17 : 165-168, 1989

2) Salem $\mathrm{HH}$, Maruyama I, Ishii $\mathrm{H}$, et al: Isolation and characterization of thrombomodulin from human placents. J Biol Chem 259: 12246 $-12251,1984$

3) Esmon CT, Owen WG: Identification of endothelial cell cofactor for thrombincatalyzed activation of protein C. Proc Natl Acad Sci USA $78: 2249-2252,1981$

4）石井秀美, 風間睦美：トロンボモジュリン.血液と 脈管 $20: 496-505,1989$

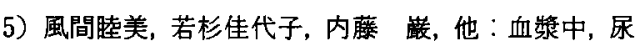
中 thrombomodulinの正常值とその测定の臨床 的意義. 厚生省特定疾患血液凝固異常症調查研究 班，昭和63年度報告書， $\mathrm{p} 45-48,1989$

6）青木延雄, 高野省吾, 大玉信一，他：Thrombomodulinの各種病態における血中浱度. 厚生省 特定疾患血液凝固異常症調查研究班，昭和63年度 報告書, $\mathrm{p} 49-52,1989$

7) Maruyama I, Bell CE, Majerus PW : Thrombomodulin is found on endthelium of arteries, veins, capillaries and lymphatics, and on syncytiotrophoblast of human placenta. J Cell Biol 101 : 363-371, 1985

8) DeBault LE, Esmon NL, Olson JR, et al: Distribution of the thrombomodulin antigen in the rabbit vasculature. Lab Invest $54: 172-178$, 1986

9) Iwabuchi $S$, Yoshida $Y$, Kamogawa A, et al: Plasma thrombomodulin in liverdiseases. Gastro. enterol Jpn $25: 661,1990$

10) Fujiwara $K$, Ogata I, Ohta $Y$, et al : Intravascular coagulation in acute liver failure in rats and its treatment with antithrombin III. Gut 29 : 1103-1108, 1988

11) Yamada $S$, Ogata I, Hirata $K$, et al: Intravascular coagulation in the development of massive hepatic necrosis induced by Corynebacterium parvum and endotoxin in rats. Scand J Gastroenterol $24: 293-298,1989$

12）藤原研司，名越澄子：急性肝资の劇症化はなぜお こるか. 治療学 $24: 278-281,1990$ 


\title{
Clinical significance of serum level of thrombomodulin in several liver diseases: especially in acute liver failure
}

\author{
Kenji Mori*, Hiroyuki Shirasawa*, Michiari OKudA*, Kozo Kayano*, Aogu Yamashita*, \\ Masafumi KuBota*, Kazuyuki Takenaka*, Satoyoshi Yamashita*, \\ Isao SAKAIDA*, Kazutoshi SANUKI**, Mitsuru YASUNAGA*, \\ Youhei FUKUMOTO* and Kiwamu OKITA*
}

We measured serum level of thrombomodulin (TM), which is known to be a maker of injured vascular endothelial cell, in several liver diseases. In the patients of acute liver failure, significant increase of serum level of TM was observed, as compared with acute hepatitis. Although it has been noted that there is a tendency of correlation between serum level of TM and creatinine, remarkable increase of serum TM in acute liver failure was observed in the patients without renal failure. These results suggest that a increase of serum level of TM predict the development of with acute liver failure. This observation indicated possible involvement of intravascular coagulation in pathogenesis of acute liver failure.

* The First Department of Medicine, Yamaguchi University (Ube)

** Department of Critical Care Medicine, Yamaguchi University (Ube) 